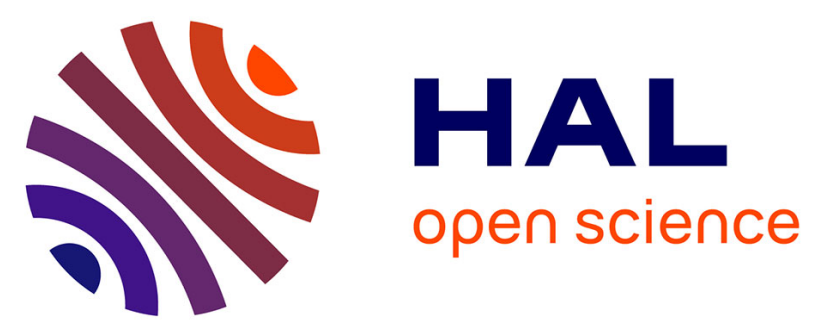

\title{
Back-bias impact on variability and BTI for 3D-monolithic 14nm FDSOI SRAMs applications
}

D. Bosch, F. Andrieu, X. Garros, L. Ciampolini, A. Makosiej, O. Weber, J. Lacord, J. Cluzel, B. Giraud, G. Cibrario, et al.

\section{- To cite this version:}

D. Bosch, F. Andrieu, X. Garros, L. Ciampolini, A. Makosiej, et al.. Back-bias impact on variability and BTI for 3D-monolithic 14nm FDSOI SRAMs applications. 2019 Joint International EUROSOI Workshop and International Conference on Ultimate Integration on Silicon (EUROSOI-ULIS), Apr 2019, Grenoble, France. pp.1-4, 10.1109/EUROSOI-ULIS45800.2019.9041890 hal-02998370

\section{HAL Id: hal-02998370 \\ https://hal.science/hal-02998370}

Submitted on 19 Nov 2020

HAL is a multi-disciplinary open access archive for the deposit and dissemination of scientific research documents, whether they are published or not. The documents may come from teaching and research institutions in France or abroad, or from public or private research centers.
L'archive ouverte pluridisciplinaire HAL, est destinée au dépôt et à la diffusion de documents scientifiques de niveau recherche, publiés ou non, émanant des établissements d'enseignement et de recherche français ou étrangers, des laboratoires publics ou privés. 


\title{
Back-bias impact on variability and BTI for 3D- monolithic 14nm FDSOI SRAMs applications
}

\author{
D. Bosch ${ }^{1,3}$, F. Andrieu ${ }^{1}$, X. Garros ${ }^{1}$, L. Ciampolini ${ }^{1,2}$ A. Makosiej ${ }^{1}$, O. Weber ${ }^{1,2}$, J. Lacord ${ }^{1}$, J. Cluzel ${ }^{1}$, B. Giraud ${ }^{1}$, \\ G. Cibrario $^{1}$, L. Brunet ${ }^{1}$, P. Batude ${ }^{1}$, C. Fenouillet-Béranger ${ }^{1}$, D. Lattard ${ }^{1}$, J. P. Colinge ${ }^{1}$, F. Balestra ${ }^{3}$, M. Vinet $^{1}$ \\ ${ }^{1}$ CEA-LETI, Univ. Grenoble Alpes, 17 rue des Martyrs, 38054 France ; ${ }^{2}$ STMicroelectronics, 850 rue Jean Monnet, \\ F38926 Crolles ; ${ }^{3}$ Univ. Grenoble Alpes, CNRS, Grenoble INP, IMEP-LAHC, F-38000 France
}

\begin{abstract}
We fabricated and characterized $14 \mathrm{~nm}$ planar Fully-Depleted-Silicon-On-Insulator (FDSOI) $\quad 0.078 \mu \mathrm{m}^{2}$ SRAM cells. Temporal and spatial variability as well as sensibility to temperature, supply voltage $\left(V_{\text {DD }}\right)$ and back bias $\left(V_{\text {well }}\right)$ are extracted. These data evidence that the 14nm SRAM is read-limited, which could be improved by a smart back-bias management [1]. In this work we demonstrate a $50 \mathrm{mV}$ Static Noise Margin (SNM) variability improvement (at $\left.V_{D D}=0.8 \mathrm{~V}\right)$ by back-bias, without additional BTI stress. Such an assist technique can be eventually leveraged at fine-grain by 3D monolithic integration, owing to local back-planes.
\end{abstract}

Keywords- 3D-monolithic; FDSOI; BTI stress; Supply Read Retention Voltage; SRAM margins; variability

\section{INTRODUCTION}

3D-monolithic integration, also named 3D sequential, consists in stacking active device layers on top of each other in a sequential manner on a given wafer substrate. This technology improves digital performance by reducing the wire length [2]. Moreover, it enables the integration of local back-planes (Figs 1-2), which can be dynamically biased in order to improve the performance of standard cells [3] and SRAMs [1] without area overhead. In order to verify if this fine-grain assist can be also used to compensate spatial variability with high reliability, we measure in this work, the impact of backbias on $14 \mathrm{~nm}$ planar FDSOI SRAM variability and BTI.

\section{CHARACTERIZATION OF 14 FDSOI SRAMS}

High-density (HD, 0.078 $\mu \mathrm{m}^{2}$ ) and High-current (HC, $\left.0.098 \mu \mathrm{m}^{2}\right) 14 \mathrm{~nm}$ planar FDSOI SRAMs have been fabricated on silicon channel with a single p-type metal gate and single p-doped well (SPWELL) [4]. SRAM typical figures of merits, SNM and Write Noise Margin (WNM), have been electrically characterized. Considering worst-case measurements at low $\mathrm{V}_{\mathrm{DD}}$ and $125^{\circ} \mathrm{C}$ and including global variability considerations, one finds that $14 \mathrm{~nm}$ FDSOI SRAM stability is readlimited (Fig.3). In fact, to enhance SNM, standard assist technique can be used [5]. More specifically, Fig.4 shows that a Word-line (WL) underdrive by $20 \%$ improves the SNM by $37 \%$ at $\mathrm{V}_{\mathrm{DD}}=0.8 \mathrm{~V}$.

\section{A. SNM spatial compensation with back bias}

A $63-50 \mathrm{mV} / \mathrm{V}$ threshold voltage sensibility on well bias $\left(\mathrm{V}_{\text {well }}\right)$ was extracted for the HC-HD Pass-Gate (PG), respectively (Fig.5). This enables either the PG drive current to be boosted by $44 \%$ for $\mathrm{V}_{\text {well }}=2 \mathrm{~V}$ or its leakage to be reduced below $0.1 \mathrm{pA}$ for $\mathrm{V}_{\text {well }}=-2 \mathrm{~V}$ on demand (Fig.6). Since the well is shared between all devices in planar FDSOI, $\mathrm{V}_{\text {well }}<0$ strengthens PMOS Pull-Up (PU) with respect to NMOS (PG, Pull-Down PD), helping the PU to maintain $\mathrm{BLTI}=1$ and $\mathrm{BLFI}=0$ during the read operation. On the contrary, using $\mathrm{V}_{\text {well }}>0$ improves the $\mathrm{PG} / \mathrm{PU}$ strength ratio (and so the WNM). Thus, the sensibility of SRAM to the back bias can be used to assist the read $\left(\mathrm{V}_{\text {well }}<0\right)$ and write $\left(\mathrm{V}_{\text {well }}>0\right)$ operation. This feature can be used as a process compensation technique, to narrow die-to-die variations, as illustrated by the $50 \mathrm{mV}$ SNM variability improvement in HD bitcells across wafer (Fig.7).

\section{B. BTI-induced dynamic variability at the bitcell level}

In order to check if this bias-bias assist influences the ageing, we measured the so-called Supply Read Retention Voltage SRRV at $125^{\circ} \mathrm{C}$ and $\mathrm{V}_{\text {DDstress }}=2 \mathrm{~V}$, which is representative of the SNM (Fig.8 and [6]). Our Bit-Line (BL) current fast measurement method is effective to extract the reduction of the read margin induced by stress (Fig. 9 and [6]). $\triangle$ SRRV distributions at different stress times for $\mathrm{V}_{\text {well }}=0$ and $-0.8 \mathrm{~V}$ are reported in Fig. 10. Same ageing is observed for both positive and negative $\mathrm{V}_{\text {well }}$, proving that back biasing does not degrade the BTI reliability. Finally, $\mathrm{V}_{\text {well }}=-0.8 \mathrm{~V}$ boosts SRRV by $65.5 \mathrm{mV}-38.1 \mathrm{mV}$ on fresh bitcells and after stress, respectively (Figs 11-12).

\section{PERSPECTIVES}

We provide guidelines to improve SNM variability in $14 \mathrm{~nm}$ SRAM cells without ageing drawback. This opens the path towards a fine-grain back-bias assist technique using the unique features of $3 \mathrm{D}$ monolithic CoolCube $\mathrm{CM}^{\mathrm{TM}}$ integration.

\section{REFERENCES}

[1] D. Bosch et al., VLSI-TSA, 2019, forthcoming

[2] F. Clermidy et al., S3S, 2015, pp. 1-4.

[3] F. Andrieu et al., Tech. Dig. IEDM, 2017, p. 20.3.1-20.3.4.

[4] O. Weber et al., 2014 Symposium on VLSI Technology, 2014, pp. 1-2

[5] Guo, Z. et al., IEEE Journal of Solid-State Circuits 44, 2009, 3174-3192

[6] Husseini et al., IEEE TED 61, 2014, 3991-3999 


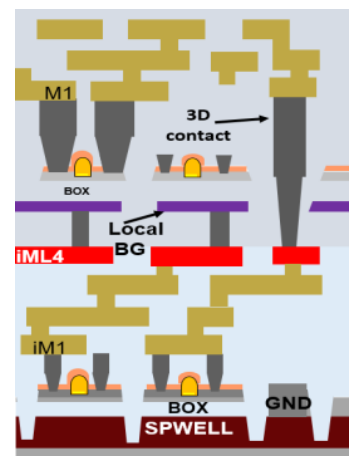

Fig.1: Schematic stack of CoolCube $^{\mathrm{TM}} 14 \mathrm{~nm}$ Design Kit with a via between the back gate and the upper intermediate metal line.

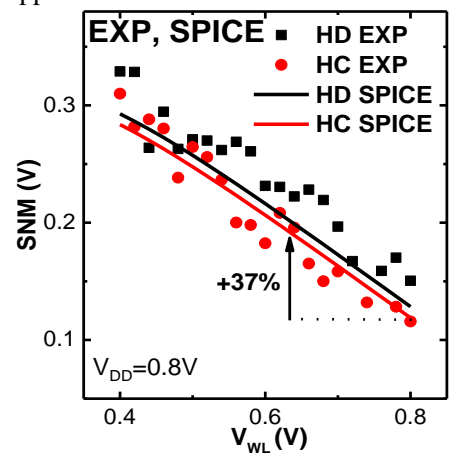

Fig.4: Exp vs. SPICE SNM in function of WL voltage (worldline underdrive read assist).

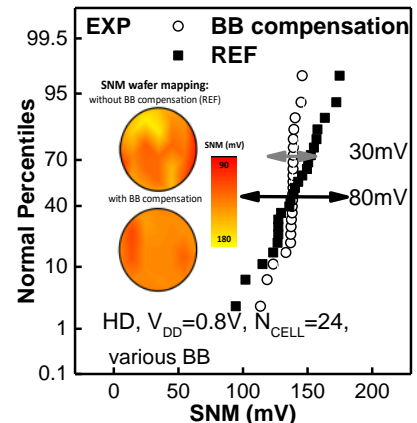

Fig.7: Exp. SNM distribution before and after back bias compensation.

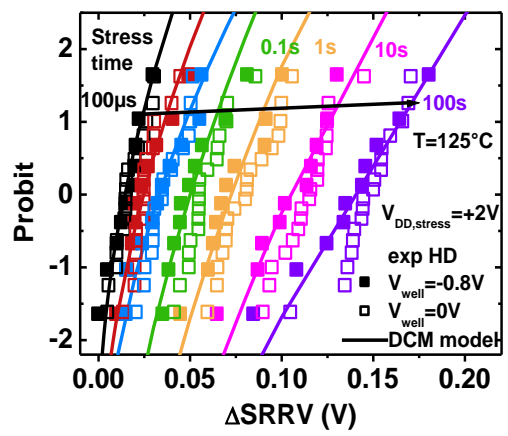

Fig.10: Experimental $\triangle$ SRRV distribution on $\sim 20$ bitcells for two $\mathrm{V}_{\text {well }}$ polarizations and fitted using the model [6].

\begin{tabular}{|c|c|c|}
\hline $\begin{array}{c}\text { FOM } \\
(\mathrm{mV})\end{array}$ & $\begin{array}{c}\text { High- } \\
\text { Density } \\
(\mathrm{HD})\end{array}$ & $\begin{array}{c}\text { High- } \\
\text { Current } \\
(\mathrm{HC})\end{array}$ \\
\hline $\begin{array}{c}\mathrm{SNM} \\
\left(\mathrm{T}=25^{\circ} \mathrm{C},\right. \\
\left.\mathrm{V}_{\mathrm{DD}}=0.8 \mathrm{~V}\right)\end{array}$ & 139 & 148 \\
\hline $\begin{array}{c}\mathrm{WNM} \\
\left(\mathrm{T}=25^{\circ} \mathrm{C},\right. \\
\left.\mathrm{V}_{\mathrm{DD}}=0.8 \mathrm{~V}\right)\end{array}$ & 320 & 351 \\
\hline $\begin{array}{c}\mathrm{SNM} \\
\left(\mathrm{T}=125^{\circ} \mathrm{C},\right. \\
\mathrm{V}_{\mathrm{DD}}=0.55 \\
\mathrm{~V})\end{array}$ & 68 & 88.5 \\
\hline
\end{tabular}
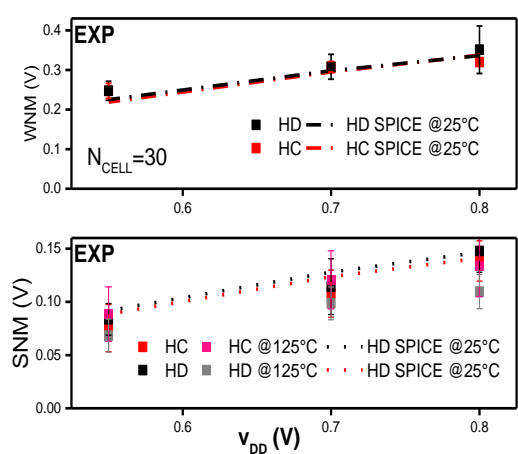

Fig.2: SRAM schematics. The additionnal terminals provided by CoolCube $^{\mathrm{TM}}$ technology are highlited in red. BTI setup is indicated in gray.

Fig.3: Right: Read and write stability, Home made SPICE model $v s$. Experimental for different $\mathrm{V}_{\mathrm{DD}}$ and temperature. Left: SNM-WNM extracted values from graph.

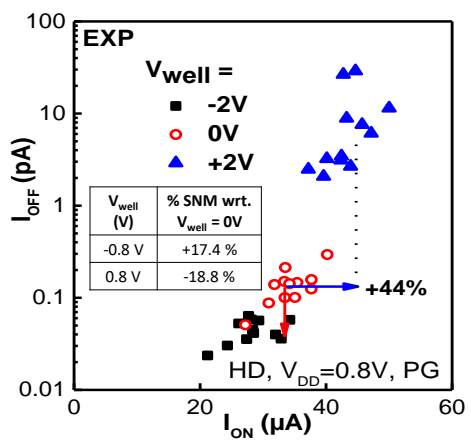

Fig.6: Exp. High density Pass Gate $\mathrm{I}_{\mathrm{OFF}}\left(\mathrm{I}_{\mathrm{ON}}\right)$ for different $\mathrm{V}_{\text {well. }}$ SNM vs. $\mathrm{V}_{\text {well }}$ (insert)

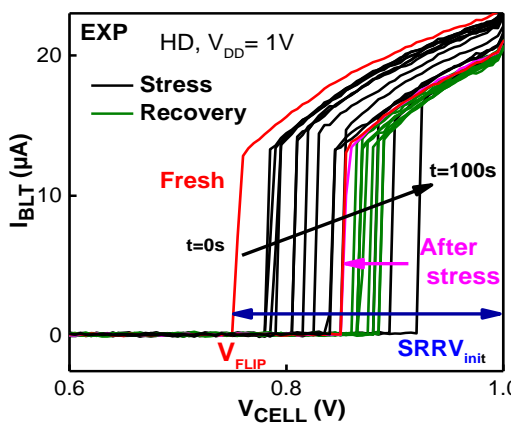

Fig.9: SRRV measured on a bitcell during stress \& recovery.

SRAM cell reliability characterisation [6].

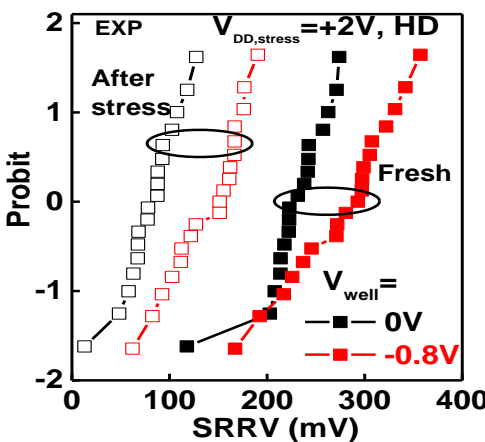

Fig.11: Fresh and after stress SRRV distribution for different p-well biasing.

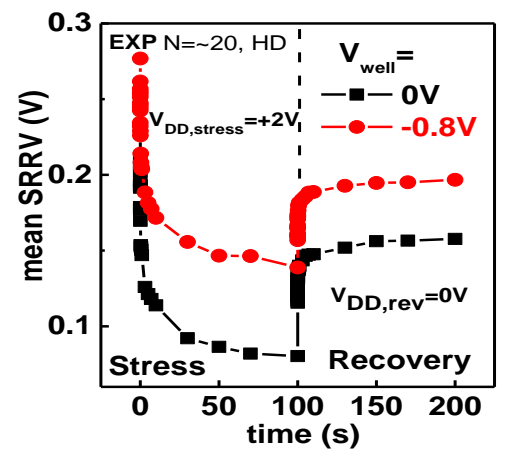

Fig.12: $\mu_{\text {SRRV }}$ during stress and recovery. A $-0.8 \mathrm{~V} \mathrm{~V}_{\text {well }}$ biasing achieves better stability.

ACKNOWLEDGMENTS: This work was supported by French Public Authorities through LabEx Minos ANR-10-LABX-55-01. 